\title{
Late recurrent post-transplant primary biliary cirrhosis in British Columbia
}

\author{
ERIC M YOSHIDA MD FRCPC, R ANDREW SINGH MD, ROBERT K VARTANIAN MD CM DABP, DAVID A OWEN MD FRCPC, \\ SIEGFRIED R ERB MD FRCPC, CHARLES H SCUDAMORE MD FRCSC
}

EM Yoshida, RA SINGH, RK VARTANiAN, DA OwEN, SR ERB, CH SCUDAMORE. Late recurrent post-transplant primary biliary cirrhosis in British Columbia. Can J Gastroenterol 1997;11(3):229-233. Late recurrent primary biliary cirrhosis (PBC) following orthotopic liver transplant remains a controversial topic. The first documented case of recurrence occurring in 16 patients transplanted for $\mathrm{PBC}$ and followed at the authors' institution for longer than one year is presented. A 54-year-old man transplanted for PBC developed a cholestatic pattern of enzyme elevation on post-transplant day (PTD) 1305. Repeat antimitochondrial antibody was strongly positive (1:300 to 1:400). A liver biopsy revealed severe bile duct damage, lymphocytic cholangitis, focal periductal noncaseating granuloma and minimal endotheliitis. Recurrent PBC was diagnosed. At the time of orthotopic liver transplant this patient received induction immunosuppression with OKT3 crossed over to cyclosporine (CsA), azathioprine (AZA) and prednisone. AZA was discontinued early and maintenance CsA tapered to a target trough level of 150 to $200 \mathrm{ng} / \mathrm{mL}$ by PTD 365. Prednisone was withdrawn by PTD 664. CsA levels during PTDs 1225 to 1305 (before elevation of hepatobiliary enzymes) were below target at 114 to $166 \mathrm{ng} / \mathrm{mL}$. Of the 16 patients, all but three were maintained on CsA, AZA and prednisone. One was on CsA (trough levels on target) and AZA; the other two, including the patient with recurrent $\mathrm{PBC}$, were on CsA only. The trough CsA level of the patient without recurrent PBC has been within the target range. The authors speculate that the underlying defect in immunoregulation in $\mathrm{PBC}$ persists post-transplant and that in the patient without recurrent PBC this defect was unmasked by lowered maintenance immunosuppression allowing recurrence of $\mathrm{PBC}$ in a previously stable liver allograft.

Key Words: Primary biliary cirrhosis, Recurrent symptoms, Transplantation

\section{Récurrence tardive d'une cirrhose biliaire primaire post-transplantation en Colombie-Britannique}

RÉSUMÉ : La récurrence tardive d'une cirrhose biliaire primaire (CBP) après une transplantation hépatique orthotopique reste un sujet controversé. Le premier cas documenté de récurrence survenant dans un groupe de 16 patients transplantés pour une CBP, et suivis pendant plus d'un an à l'hôpital où exerce l'auteur, est présenté. Un Canadien français de 54 ans, transplanté pour une CBP à développé une cholestase caractérisée par une hausse des enzymes au jour 1305 post-transplantation. L'examen répété des anticorps antimitochondriaux était fortement positif (1:300 à 1:400). Une biopsie du foie a mis en évidence une grave atteinte des canaux biliaires, une cholangite lymphocytaire, un granulome focal péricanalaire non caséeux et une endothéliite minimale. Un diagnostic de CBP récurrente a été posé. Au moment de la transplantation hépatique orthotopique, ce patient avait reçu un traitement immunosuppresseur initial avec de l'OKT3 croisé avec de la ciclosporine (CsA), de l'azatioprine (AZA) et de la prednisone. On a cessé d'administrer l'AZA tôt tandis que le traitement d'entretien à la CsA a été diminué progressivement jusqu'à un niveau cible minimal de 150 à $200 \mathrm{ng} / \mathrm{mL}$ au $365^{\mathrm{e}}$ jour post-transplantation. On a supprimé la prednisone au $664^{\mathrm{e}}$ jour post-transplantation. Les niveaux de CsA pendant la période allant du $1225^{\mathrm{e}}$ jour au $1305^{\mathrm{e}}$ jour post-transplantation (avant la hausse des enzymes hépatobiliaires) était inférieurs au point cible, soit entre 114 et $166 \mathrm{ng} / \mathrm{mL}$. Des 16 patients, tous sauf trois ont continué à recevoir de la CsA, de l'AZA et de la prednisone. Un recevait de la CsA (niveau minimal adéquat) et de l'AZA ; les deux autres patients, y compris le patient souffrant d'une CBP récurrente, recevaient seulement de la CsA. Le niveau minimal de CsA du patient sans CBP récurrente se trouvait dans les limites fixées. Les auteurs ont émis l'hypothèse que l'anomalie sous-jacente dans l'immunorégulation, dans la $\mathrm{CBP}$, persiste dans la période post-transplantation, et que dans le cas du patient sans CBP récurrente, cette anomalie avait été démasquée en diminuant le traitement d'entretien immunosuppresseur, permettant ainsi une récurrence de la CBP dans une allogreffe hépatique auparavant stable.

Departments of Medicine, Anatomic Pathology, and Surgery, University of British Columbia; and the British Columbia Transplant Society, Vancouver, British Columbia

Correspondence: Dr Eric M Yoshida, British Columbia Transplant Society, East Tower, 4th Floor, 555 West 12th Avenue, Vancouver,

Received for publication April 23, 1996. Accepted May 24, 1996 
$\mathrm{O}$ ver the past 15 years orthotopic liver transplantation has proven to be efficacious in the management of patients with end-stage primary biliary cirrhosis (PBC) (1). Referral of these patients for transplantation assessment is now routine. Although it may be presumed by both patients and physicians that successful transplantation will completely cure the original disease, this point is controversial. In 1982 Neuberger et al (2) from the King's College Hospital Liver Unit (London, United Kingdom) reported three patients with cholestatic jaundice who were thought to have recurrent $\mathrm{PBC}$. This initial report was followed up seven years later with a report of 13 patients, including the three originally reported, who were felt to have recurrent PBC (3). Nine of the 13 had liver biopsies that were interpreted as compatible with $\mathrm{PBC}$ recurrence. Other centres have since reported recurrent PBC (4-6). However, some centres have also reported a failure to find clear evidence of recurrent $\mathrm{PBC}$ in their patients $(7,8)$. Furthermore, one of the patients reported by the King's College Hospital's group (3) was recently discovered to have chronic rejection - rather than recurrent $\mathrm{PBC}$ (9).

We report the first documented case of late recurrent $\mathrm{PBC}$ post-transplant at our centre. The discovery of this patient prompted a review of all our PBC patients who were transplanted more than one year ago in an attempt to discover any factors that may have contributed to post-transplant PBC recurrence.

\section{METHODS}

After identification of the patient reported below, records of the British Columbia Transplant Society were reviewed to identify all patients transplanted for $\mathrm{PBC}$ (including patients transplanted at other centres but followed in British Columbia). The Vancouver Hospital Transplant Clinic charts of all patients more than 365 days post-transplant as of February 1, 1996 were reviewed. According to the protocol of the transplant clinic, liver enzymes and whole blood trough cyclosporine (CsA) levels (monoclonal radioimmunoassay, Incstar Cyclotrac, Minnesota) were obtained every two weeks. The target trough CsA level for patients after posttransplant day (PTD) 365 is 150 to $200 \mathrm{ng} / \mathrm{mL}$. Some patients had been converted from soft gelatin capsule CsA to the microemulsion formulation. According to Vancouver Hospital Transplant Clinic protocols, the target trough CsA level for patients 365 days after transplantation taking microemulsion formulation CsA is 120 to $150 \mathrm{ng} / \mathrm{mL}$. Liver biopsies were obtained for persistent elevations in alkaline phosphatase (ALP), gamma-glutamyl transpeptidase (GGT), aspartate aminotransferase (AST) or alanine aminotransferase (ALT). All biopsies were examined for features of acute rejection, which have been previously described (10). Antimitochondrial antibody (AMA) was ordered at the discretion of the transplant physician. Immunosuppressive medication and liver enzymes were recorded from the time of last follow-up for all patient charts reviewed. As well, the last reported liver biopsy report for each patient was reviewed. Criteria for the diagnosis of recurrent PBC included persistently elevated hepatobiliary enzymes, a positive AMA equivalent to a titre of 1:80 post-transplant and a liver biopsy with compatible histological features (11).

\section{CASE PRESENTATION}

A 54-year-old man of French-Canadian descent received a liver allograft for end-stage PBC 3.5 years previously. Before transplantation serum liver enzymes were ALP $232 \mathrm{U} / \mathrm{L}$ (normal 45 to $125 \mathrm{U} / \mathrm{L}$ ); GGT $129 \mathrm{U} / \mathrm{L}$ (normal less than $50 \mathrm{U} / \mathrm{L}$ ); total bilirubin $69 \mu \mathrm{mol} / \mathrm{L}$ (normal less than $22 \mu \mathrm{mol} / \mathrm{L}$ ); AST $103 \mathrm{U} / \mathrm{L}$ (normal 19 to $38 \mathrm{U} / \mathrm{L}$ ); and ALT $60 \mathrm{U} / \mathrm{L}$ (normal 10 to $55 \mathrm{U} / \mathrm{L}$ ). Serology for AMA three years pretransplant was positive at a titre of 1:640; repeat AMA a year before transplant was positive at 1:320. Serology for antinuclear antibody and antismooth muscle antibodies were negative, as were viral markers for hepatitis B and C.

Orthotopic liver transplantation was undertaken with standard immunosuppressive induction consisting of OKT3 for nine days after transplantation, overlapped with CsA on PTD 7, prednisone $20 \mathrm{mg} /$ day and azathioprine (AZA) $100 \mathrm{mg} /$ day. Pathological examination of the explanted liver revealed micronodular cirrhosis, prominent bile ductular proliferation, periportal lymphocytic infiltrate, piecemeal necrosis and cholestasis, findings consistent with stage IV PBC. Early in the post-transplant period, AZA was discontinued secondary to leukopenia, and immunosuppression was continued with CsA and prednisone.

Maintenance immunosuppression was gradually tapered; by PTD 365, CsA was titrated to achieve a target whole blood trough level of 150 to $200 \mathrm{ng} / \mathrm{mL}$, compared with 350 to $400 \mathrm{ng} / \mathrm{mL}$ in the first post-transplant month. Prednisone was slowly tapered from $20 \mathrm{mg} /$ day and discontinued entirely by PTD 664 because of persistent obesity. Allograft function remained stable throughout PTD 1175 with no episodes of acute rejection and unremarkable liver enzymes at PTD 1175: ALP $97 \mathrm{U} / \mathrm{L}$, GGT $69 \mathrm{U} / \mathrm{L}$, AST $10 \mathrm{U} / \mathrm{L}$ and ALT $13 \mathrm{U} / \mathrm{L}$. The CsA trough level from PTDs 1225 to 1305 was between 114 and $166 \mathrm{ng} / \mathrm{mL}$. On PTD 1305 the hepatobiliary enzymes were noted to be elevated: ALP was $286 \mathrm{U} / \mathrm{L}$, GGT $450 \mathrm{U} / \mathrm{L}$, AST $63 \mathrm{U} / \mathrm{L}$ and ALT $63 \mathrm{U} / \mathrm{L}$. Repeat liver chemistry on PTD 1309 revealed ALP to be 303 U/L, GGT $474 \mathrm{U} / \mathrm{L}$ and AST $77 \mathrm{U} / \mathrm{L}$. An abdominal ultrasound did not reveal any dilated biliary ducts or stones, and a core liver biopsy was obtained on PTD 1311.

The liver biopsy (Figure 1) revealed minimal (and probably artefactual) evidence of endotheliitis, patchy portalbased mononuclear infiltrates and areas of severe bile duct damage with lymphocytic cholangitis accompanied by a focal portal-based periductal noncaseating granuloma. The biopsy was compatible with PBC based on histopathological features previously described (11). A repeat AMA was strongly positive at $3+$ (equivalent to a titre of 1:300 to 1:400).

Because of possible acute rejection the patient was treated with pulse methlyprednisilone $1 \mathrm{~g}$ intravenously daily for three days, followed by prednisone $20 \mathrm{mg} /$ day. Follow-up serum liver enzymes gradually improved such that on PTD 1353, ALP was $118 \mathrm{U} / \mathrm{L}$, GGT $267 \mathrm{U} / \mathrm{L}$ and AST $19 \mathrm{U} / \mathrm{L}$. 

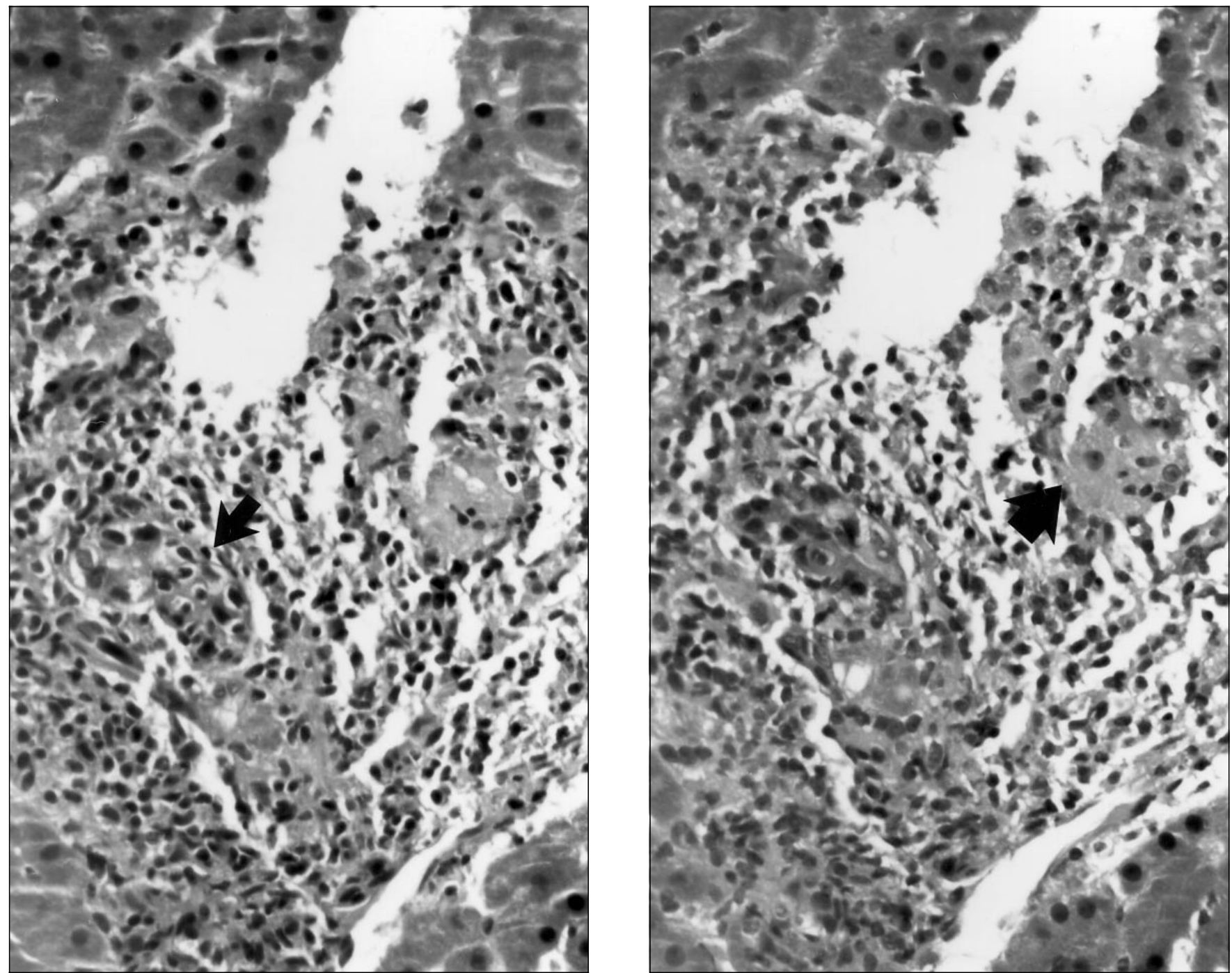

Figure 1) Left Photomicrograph of the liver biopsy obtained on post-transplant day 1311. Accompanying the florid duct lesion (arrow) is a periductal noncaseating granuloma (hematoxylin and eosin, x110). Right A $5 \mu \mathrm{m}$ step section that best demonstrates the portal-based noncaseating granuloma (arrow) (hematoxylin and eosin, x110)

Ursodeoxycholic acid was started at $500 \mathrm{mg}$ tid. Serum liver chemistry on PTD 1402 revealed ALP of $88 \mathrm{U} / \mathrm{L}$, GGT $115 \mathrm{U} / \mathrm{L}$ and AST $13 \mathrm{U} / \mathrm{L}$.

On the basis of the acute cholestatic pattern of liver enzymes, strongly positive AMA and liver biopsy revealing changes consistent with $\mathrm{PBC}$, but atypical for acute cellular rejection alone, a diagnosis of recurrent allograft $\mathrm{PBC}$ was made.

\section{RESULTS}

From 1989 until February 1, 1996, 23 patients transplanted for PBC (20 transplanted at the Vancouver Hospital, three transplanted in another province) were identified from the British Columbia Transplant Society records. Sixteen patients were identified who were PTD 365.

Maintenance immunosuppression for 13 patients consisted of CsA, AZA and prednisone. One patient was maintained on microemulsion formulation CsA (trough levels 141 to $223 \mathrm{ng} / \mathrm{mL}$ ) and AZA, and two patients, including the one described above, were maintained on CsA alone. The trough CsA level of the patient without recurrent PBC (on soft gelatin capsule CsA) was 153 to $221 \mathrm{ng} / \mathrm{mL}$.

Nine of the 16 patients had normal liver enzymes (ALP, GGT, AST and ALT) throughout the last follow-up. Seven patients, including the patient reported with recurrent PBC, had elevated hepatobiliary enzymes. The six remaining patients with elevated hepatobiliary enzymes were all on triple immunosuppression. The first patient suffered from recurrent biliary strictures and portal vein thrombosis, and died secondary to complications of portal hypertension. The second patient with previously stable liver enzymes developed an acute elevation of hepatobiliary enzymes (ALP $287 \mathrm{U} / \mathrm{L}$ and GGT 362 U/L) on PTD 589. Liver biopsy revealed late acute rejection with no features of PBC. The third and fourth patients had chronically elevated hepatobiliary enzymes more than 1.5 times the upper limit of normal with negative follow-up AMA and previous documented acute rejection on liver biopsy during the first year. The third patient also 
had a history of chronic post-transplant alcohol abuse. The fifth patient, post-transplant AMA status unknown, had persistently elevated hepatobiliary enzymes up to and including PTD 1931. The last liver biopsy at PTD 618 revealed acute rejection with significant fibrosis and decreased bile ducts. The sixth patient developed persistently elevated liver enzymes (ALP $228 \mathrm{U} / \mathrm{L}$, GGT $365 \mathrm{U} / \mathrm{L}$ and AST $88 \mathrm{U} / \mathrm{L}$ ) at PTD 1528. A liver biopsy was refused. She was started on ursodeoxycholic acid with complete normalization of liver enzymes by PTD 1703 (ALP 84 U/L, GGT 48 U/L, AST $28 \mathrm{U} / \mathrm{L}$ and ALT $28 \mathrm{U} / \mathrm{L}$ ). A repeat AMA (ELISA) was positive at a titre of 1:320.

\section{DISCUSSION}

Although recurrence of original disease in liver allografts is well recognized in patients transplanted for viral hepatitis $(12,13)$ and malignancy $(14)$, it is less well appreciated for autoimmune diseases such as PBC. This is probably because allograft recipients are continued on potent immunosuppressive medications on a long term basis. Further, two of the drugs traditionally deemed the cornerstones of post-transplant immunosuppressive regimens, $\mathrm{CsA}$ and corticosteroids, have been demonstrated to be of efficacy to treat active PBC $(15,16)$, albeit with significant drug-related adverse effects. The basic underlying defect in immunoregulation that produces $\mathrm{PBC}$, however, is expected to persist after liver transplantation.

We diagnosed late recurrent $\mathrm{PBC}$ in our patient on the basis of elevated hepatobiliary enzymes, a strongly positive AMA at the time of diagnosis and the histological finding of a 'florid duct lesion', consisting of characteristic ductal epithelial changes with lymphocytic cholangitis accompanied by a periductal granuloma. The florid duct lesion on liver biopsy has been the characteristic finding in all series reporting recurrent post-transplant $\mathrm{PBC}(2-6,17)$, although not all patients in these reports have had periductal granulomas $(3,6)$. The AMA post-transplant classically falls to low titres in the early post-transplant period and may rise to higher titres as the post-transplant period progresses $(3,7)$. Our patient with recurrent $\mathrm{PBC}$ had a strongly positive posttransplant AMA, which was similar to his pretransplant AMA. Although recurrent PBC has been described in allograft recipients with an undetectable AMA (5), we interpret the strongly positive AMA in our patient to support a diagnosis of recurrent PBC. In comparison, two of our patients with chronically elevated liver enzymes following episodes of rejection within the first transplant year had, on recent repeat testing, a negative AMA.

The possibility of allograft rejection must be considered when determining the diagnosis in a transplant recipient with inflammatory bile duct damage on biopsy. As occurs in $\mathrm{PBC}$, biliary epithelium is also a prime target of rejection, which presents with biliary injury in its early stages (10). Indeed, a patient included in a widely cited study (3) of recurrent $\mathrm{PBC}$ was recently found, on examination of the previously transplanted explanted liver, to have chronic rejection rather than $\mathrm{PBC}$ (9). This patient did not have portal granulomas in the original report (3). As well, Gouw and associates (8) could not find any histological differences in biliary damage between a group of patients transplanted for $\mathrm{PBC}$ and a non-PBC group on protocol biopsies. Despite these reports, and recognizing that there could be overlap in the histological features of rejection and recurrent PBC, there also appear to be features that allow distinction between the two conditions. These features are presence of endothelial inflammation (endotheliitis); and presence of a mixed portal infiltrate in rejection, versus the presence of the florid duct lesion with periductal granulomas and predominantly mononuclear portal-based infiltrates in recurrent PBC. Our patient clearly had a florid duct lesion (Figure 1) with a periductal granuloma which, in this clinical setting, is diagnostic of recurrent PBC. Granulomas in recurrent PBC are often periductal, with associated ductal damage, and occur many months to years after transplantation. Recently, Ferrell and associates (18) reported the presence of portalbased granulomas in two patients with acute cellular rejection. These two patients, however, were only a short time into the post-transplant period and the granulomas were located at the edge of the portal tract away from the bile duct. In their series, Ferrell et al had no difficulty in distinguishing acute rejection from recurrent $\mathrm{PBC}$ based on histological features.

Our patient is the first at our centre to develop documented late recurrent $\mathrm{PBC}$, occurring 3.5 years post-transplant. Upon review of our patients transplanted for PBC, this patient was only one of two who had maintenance immunosuppression consisting solely of CsA. Furthermore, the CsA trough levels in the 2.5 months before the increase in hepatobiliary enzymes and confirmatory liver biopsy were below the therapeutic target. Because the primary immunological abnormality responsible for $\mathrm{PBC}$ can be expected to persist after transplantation, we speculate that reduced maintenance immunosuppression may have been a factor in the development of recurrent PBC. One of the current theories is that $\mathrm{PBC}$ is a disease of impaired immunoregulation (19). If an underlying defect in immunotolerance remains, then a reduction in immunosuppressive medication may unmask this defect by allowing activation of the immune system's effector cells. The role of maintenance immunosuppressive medications has not been adequately assessed in most studies of recurrent PBC. In the study of Gouw et al (8), in which no recurrent $\mathrm{PBC}$ was found in their transplant population, patients were maintained on CsA and a median prednisilone dosage of $17 \mathrm{mg} /$ day at one year, $12 \mathrm{mg} /$ day after two years and then $10 \mathrm{mg} /$ day indefinitely. Most centres in North America would consider this regimen of corticosteroids to be high. On the other hand, prednisone was withdrawn in five of nine King's College Hospital patients with biopsy-proven recurrent $\mathrm{PBC}(2)$, and two centres reporting recurrent $\mathrm{PBC}$ withdrew maintenance corticosteroids after the first year (4) or sooner (6). Because prednisone has been effective in the treatment of mild PBC (16) we speculate that withdrawal of corticosteroids may be a factor in the appearance of recurrent PBC. Of interest, the King's College Hospital group has also 
reported recurrent $\mathrm{PBC}$ in two patients maintained on FK506 (tacrolimus) (17) without corticosteroids.

\section{CONCLUSIONS}

We report the first case of recurrent $\mathrm{PBC}$ at our institution. The long term clinical significance of this disease recurrence is unknown. Because PBC is a chronic disease that progresses to end-stage liver disease over many years, the situation presumably is similar in the post-transplant patient. As in pretransplant PBC (20), ursodeoxycholic acid may be of some benefit in post-transplant recurrence.

ACKNOWLEDGEMENTS: The authors express their appreciation to Heather Eggen RN and Stephen Parker RN for the dedicated care they provide to liver transplant recipients.

\section{REFERENCES}

1. Markus BH, Dickson ER, Grambsch PM, et al. Efficacy of liver transplantation in patients with primary biliary cirrhosis. N Engl J Med 1989;320:1709-13.

2. Neuberger J, Portmann B, Macdougall BRD, Calne RY, Williams R. Recurrence of primary biliary cirrhosis after liver transplantation. N Engl J Med 1982;306:1-4.

3. Polson RJ, Portmann B, Neuberger J, Calne RY, Williams R. Evidence of disease recurrence after liver transplantation for primary biliary cirrhosis. Gastroenterology 1989;97:715-25.

4. Dietze O, Vogel W, Margreiter R. Primary biliary cirrhosis (PBC) after liver transplantation. Tranplant Proc 1990;22:1501-2.

5. Balan V, Batts KP, Porayko MK, Kron RAF, Ludwig J, Wiesner RH. Histological evidence for recurrence of primary biliary cirrhosis after liver transplantation. Hepatology 1993;18:1392-8.

6. Hubscher SG, Elias E, Buckels JAC, Mayer AD, McMaster P, Neuberger JM. Primary biliary cirrhosis. Histological evidence of disease recurrence after liver transplantation. J Hepatol $1993 ; 18: 173-84$.
7. Esquivel CO, Van Thiel DH, Demetris AJ, et al. Transplantation for primary biliary cirrhosis. Gastroenterology 1988;94:1207-16.

8. Gouw ASH, Haagsma EB, Manns M, Klompmaker IJ, Slooff MJH, Gerber MA. Is there recurrence of primary biliary cirrhosis after liver transplantation? A clinicopathologic study in long-term survivors. J Hepatol 1994;20:500-7.

9. Lerut JP, Zimmermann A, Gertsch P. Late graft dysfunction after liver transplantation for primary biliary cirrhosis: disease recurrence versus chronic graft rejection. Am J Gastroenterol 1994;89:1896-8.

10. Snover DC, Freese DK, Sharp HL, Bloomer JR, Najarian JS, Ascher NL. Liver allograft rejection. An analysis of the use of biopsy in determining outcome of rejection. Am J Surg Pathol 1987;11:1-10.

11. Scheuer PJ. Primary biliary cirrhosis. Proc R Soc Med 1967;60:1257-60.

12. Samuel D, Muller R, Alexander G, et al. Liver transplantation in European patients with the hepatitis B surface antigen. N Engl J Med 1993;329:1842-7.

13. Gane EJ, Naovmov NV, Ke-Ping A, Mondelli MV, Maertens G. A longitudinal analysis of hepatitis $\mathrm{C}$ virus replication following liver transplantation. Gastroenterology 1996;110:167-77.

14. Cummings OW. Disease recurrence after orthotopic liver transplantation. Semin Diagn Pathol 1993;10:292-301.

15. Wiesner RH, Ludwig J, Lindor KD, et al. A controlled trial of cyclosporin in the treatment of primary biliary cirrhosis. N Engl J Med 1990;332:1419-24.

16. Mitchison HC, Bassendine MF, Malcolm AJ, Watson AJ, Record CO, James OF. A pilot double-blinded controlled 1 year trial of prednisilone treatment in primary biliary cirrhosis: hepatic improvement but greater bone loss. Hepatology 1990;15:336-44

17. Wong PYN, Portmann B, O'Grady JG, et al. Recurrence of primary biliary cirrhosis after liver transplantation following FK506-based immunosuppression. J Hepatol 1993;17:284-7.

18. Ferrell LD, Lee R, Brixko C, et al. Hepatic granulomas following liver transplantation. Clinicopathologic features of 42 patients. Transplantation 1995;60:926-33.

19. Suou T, Civeira MP, Kanof ME, Moreno-Otero R, Jones EA, James SP. Defective immunoregulation in primary biliary cirrhosi: CD4+, Leu- $8+T$ cells have abnormal activation and suppressor function in vitro. Hepatology 1989;10:408-13.

20. Heathcote EJ, Cauch-Dudek K, Walker V, et al. The Canadian multicenter double-blind randomized controlled trial of ursodeoxycholic acid in primary biliary cirrhosis. Hepatology 1994;19:1149-56. 


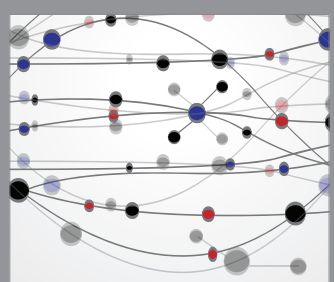

The Scientific World Journal
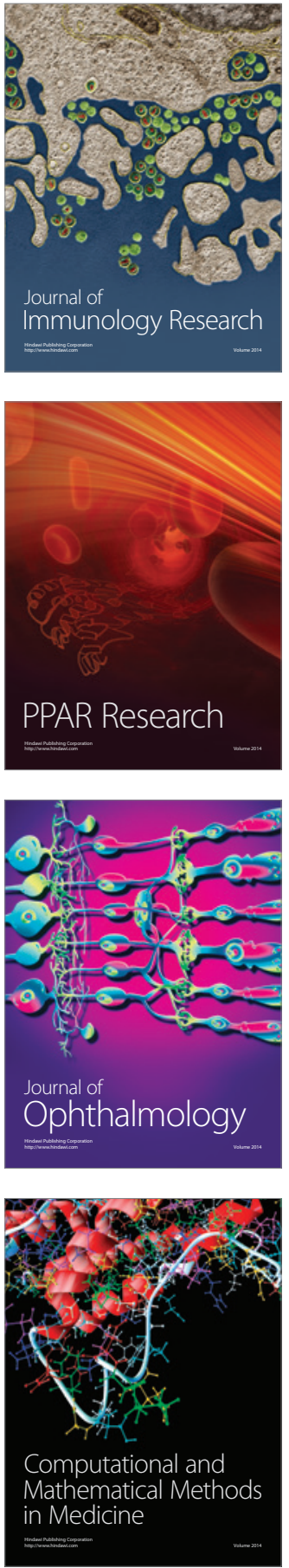

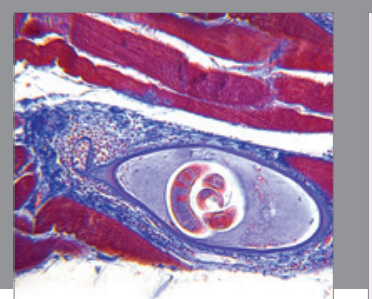

Gastroenterology Research and Practice

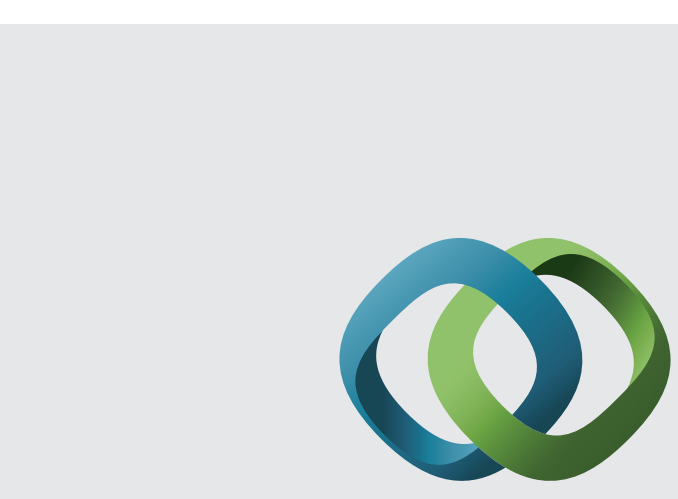

\section{Hindawi}

Submit your manuscripts at

http://www.hindawi.com
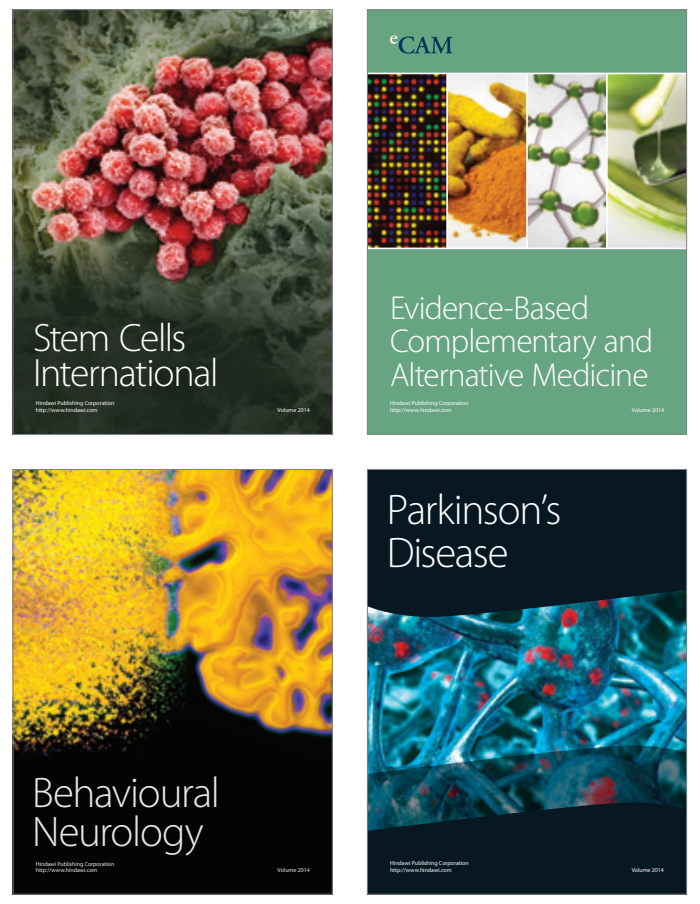
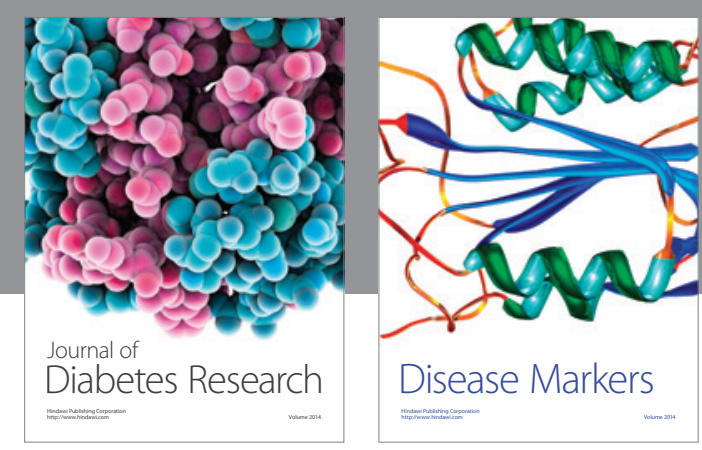

Disease Markers
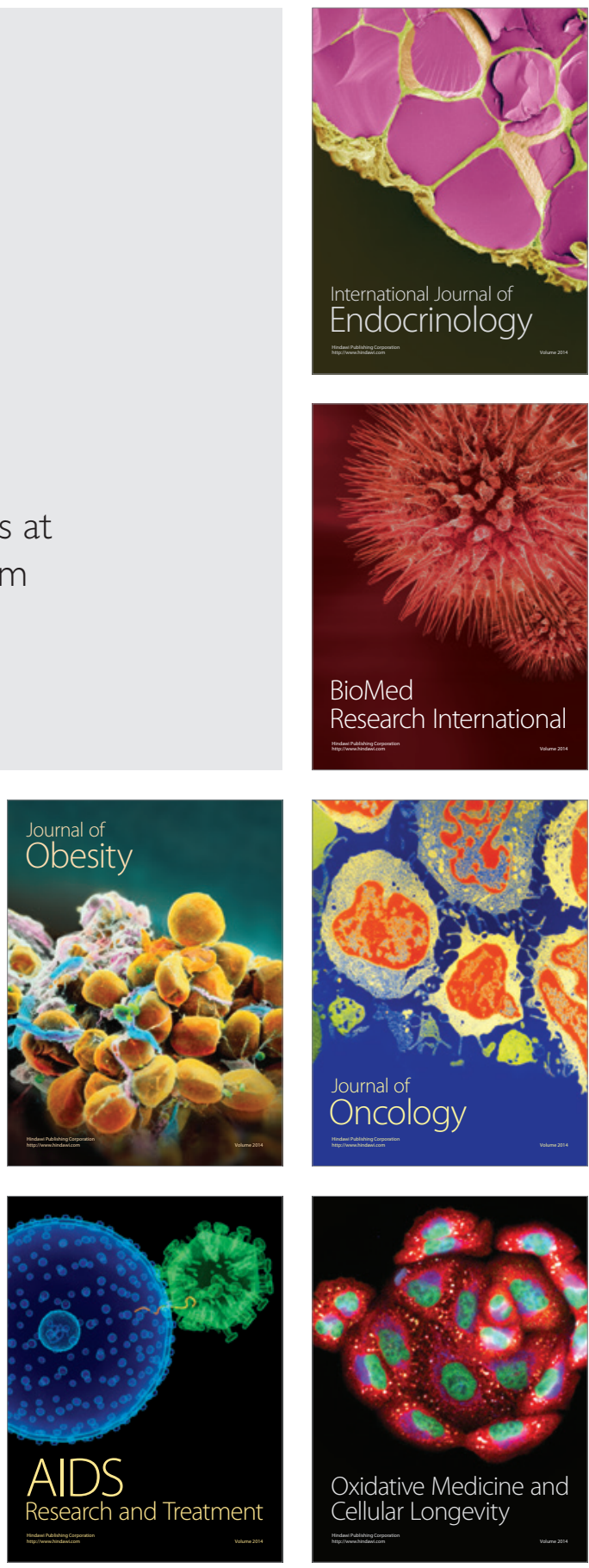